\title{
KINERJA KEUANGAN MEMODERASI STRUKTUR MODAL DAN UKURAN PERUSAHAAN TERHADAP NILAI PERUSAHAAN
}

\author{
Mochamad Fariz Irianto \\ Universitas Kanjuruhan Malang, Indonesia \\ e-mail: mochamadfarizirianto@unikama.ac.id
}

\begin{abstract}
Company value is a description of everything in the company. The description can be in the form of resources that are in the company. The research has the aim of working whether the company's performance is able to be a moderating variable for the relationship structure and firm size. Research with population using the consumer goods sector company. The sample of $17 \mathrm{com}$ panies in 2016-2018. Multiple regression data techniques. The results of the statement of capital structure have a positive effect on firm value. Firm size has a negative effect on firm value. Firm performance moderates the relationship between capital structure and firm value. Profits do not moderate the relationship between firm size and firm value.
\end{abstract}

Keywords: financial performance, capital structure, company size, firm value

\section{PENDAHULUAN}

Perusahaan yang mempunyai tujuan dalam memperoleh profitabilitas umumnya dapat memfokuskan kegiatannya dalam peningkatan nilai perusahaan hingga mampu mencapai maksimum, dapat diberikan arti nilai perusahaan ialah indikator penting yang dapat menjadi pertimbangan investor dan cerminan harga saham yang optimal, serta dalam jangka panjangnya memiliki kenaikan, makin tingginya harga saham maka makin tingginya nilai perusahaan (Wirajaya $\&$ Dewi, 2013). Penelitian ini digunakan rumus Tobin's Q dalam perhitungan nilai perusahaan. Analisis Tobin's Q dapat dikenal juga rasio Tobin's Q. Tobin's Q dihitung melalui perbandingan rasio pasar saham emiten dengan nilai buku ekuitas perusahaan. Tobin's Q ialah suatu perhitungan yang bukan hanya terlihat sisi fundamental, akan tetapi melihat seberapa jauh market menilai perusahaan pada semua aspek yang terlihat oleh khalayak luas salah satunya investor.
Banyak macam indikator yang memengaruhi nilai contohnya struktur modal. Struktur modal bisa optimal apabila diperlukan karena bisa mengoptimalkan serta menyeimbangkan pa$\mathrm{da}$ risiko serta tingkat pengembalian (return). Struktur modal ialah digunakannya utang jangka panjang pada modal pribadi, pada penelitian digunakannya struktur ekuitas dengan pengukuran debt to equity ratio yang disebut kategori rasio kewajiban (Murhadi, 2013) artinya makin tinggi rasio maka makin besar digunakannya dana utang atas modal perusahaan, yang nanti dapat memengaruhi persediaan dana dalam pemenuhan pendanaan perusahaan.

Ukuran perusahaan menjadi indikator yang memberikan pengaruh nilai perusahaan. Ukuran perusahaan dapat memengaruhi nilai perusahaan dikarenakan makin besar ukuran ataupun rentang perusahaan jadi makin bisa juga emiten diperolehnya sumber dana baik yang sifatnya pribadi maupun asing (Novari \& Lestari, 2016).

Indikator selanjutnya yang dapat memberikan pengaruhnya pada nilai perusahaan yakni 
kinerja perusahaan. Kinerja perusahaan yakni mampunya perusahaan dalam mempunyai profitabilitas pada asset, modal, ataupun utang. Kinerja perusahaan ialah kepuasan kerja perusahaan. Indikator pengukuran kinerja perusahaan yaitu return on asset (ROA). ROA ialah rasio keuangan yang berkaitan pada potensi profitabilitas serta pengukuran kekuatan perusahaan untuk menghasilkan keuntungan (Bestariningrum, 2015; Hirdinis, 2019; Manoppo \& Arie, 2016; Rahman, 2012) dengan hasil struktur modal memengaruhi dan signifikan pada nilai emiten.

Penelitian Fachrudin (2011) yang berjudul Analisis Pengarub Struktur Modal, Ukuran Perusahaan dan Agency Cost terhadap Kinerja Perusahaan memiliki hasil belum terdapatnya pengaruh struktur modal, ukuran perusahaan dan agency cost terhadap kinerja perusahaan. Penelitian Arviansyah (2013) yang berjudul Pengaruh Struktur Modal, Kinerja Keuangan Perusahaan, Pertumbuhan Perusahaan, dan Ukuran Perusahaan terhadap Nilai Perusahaan pada Perusahaan yang Terdaftar di Jakarta Islamic Index (JII) Periode 2008-2011 menjelaskan struktur modal serta kinerja keuangan memengaruhi signifikansi pada nilai perusahaan namun pertumbuhan perusahaan serta ukuran perusahaan memengaruhi negatif pada nilai perusahaan.

Terdapat peneliti terdahulu yang belum konsisten dengan fenomena yang ada. Peneliti melakukan penambahan satu variabel yaitu kinerja perusahaan sebagai moderasi. Sesuai latar belakang maka peneliti tertarik dilakukannya penelitian kembali pada penyusunan skripsi berjudul Hubungan Struktur Modal dan Ukuran Perusahaan terhadap Nilai Perusahaan Dimoderasi Kinerja Keuangan.

Permasalahan pada penelitian apakah kinerja keuangan bisa memoderasi hubungan struktur modal serta ukuran perusahaan pada nilai perusahaan.

\section{METODOLOGI}

Penelitian eksplanasi yakni melakukan pengujian keterkaitan sesama variabel yang dihipotesiskan. Tujuan penelitian menganalisis pengaruhnya dua variabel bebas, yakni struktur modal dan ukuran perusahaan, kinerja perusahaan menjadi variabel moderasi, serta nilai perusahaan menjadi variabel terikat. Metode penelitian dengan kuantitatif.

Populasi penelitian emiten sektor barang konsumsi yang ada di BEI tahun 2016-2018. Sampel emiten dengan jumlah 17 perusahaan. Sampel dipilih sesuai kriteria ditentukan. Data dianalisis dengan multiple regression analysis (MRA).

\section{HASIL DAN PEMBAHASAN}

\section{Hasil Uji Normalitas}

Pengujian normalitas melalui uji Kolmogorov Smirnov.

Tabel 1 Hasil Uji Normalitas

\begin{tabular}{|ll|r|}
\hline & & \multicolumn{2}{|c|}{ Unres } \\
\hline $\mathrm{N}$ & & 51 \\
Normal & Mean & .0000000 \\
Parameters & & Std. Deviation \\
Most Extreme & Absolute & .50028795 \\
Differences & Positive & .101 \\
& Negative & .096 \\
Kolmogorov-Smirnov Z & -.101 \\
Asymp. Sig. (2-tailed) & .720 \\
\end{tabular}

Pengujian normalitas ditunjukkan bahwa asymp sig $>5 \%$, ini mendapatkan arti data dinyatakan normal. 
Hasil Uji Autokorelasi

Tabel 2 Uji Autokorelasi

\begin{tabular}{|l|r|r|r|r|}
\hline Models & $\mathrm{R}$ & $\begin{array}{c}\mathrm{R} \\
\text { Square }\end{array}$ & $\begin{array}{c}\text { Std. Error of } \\
\text { the Estimate }\end{array}$ & \multicolumn{1}{c|}{ DW } \\
\hline 1 & $.745^{\mathrm{a}}$ & .554 & .5215862 & 1.529 \\
\hline
\end{tabular}

Uji autokorelasi melalui durbin waston. Hasil uji autokorelasi menunjukkan hasil 1,529 berada pada angka 1,55-2.46 ini berarti data atau model MRA tidak terjadi autokorelasi.

\section{Hasil Uji Multikolonieritas}

Uji autokorelasi menggunakan durbin waston.

Tabel 3 Uji Multikolonieritas

\begin{tabular}{|l|r|r|}
\hline \multirow{2}{*}{ Models } & \multicolumn{2}{|c|}{ Collinearitys Statistics } \\
\cline { 2 - 3 } & Tolerances & \multicolumn{1}{|c|}{ VIF } \\
\hline 1 (Constanta) & & \\
der & .389 & 2.570 \\
size & .909 & 1.100 \\
der roa & .267 & 3.747 \\
size roa & .396 & 2.524 \\
\hline
\end{tabular}

Pada tabel tersebut dilihat bahwa semua VIF ada pada bawah 10 dan dengan nilai tolerances di atas 0,5 maka model regresi dinyatakan bebas dari multikolinearitas.

\section{Hasil Uji Heteroskedastisitas}

Tabel 4 Uji Heteroskedastisitas

\begin{tabular}{|l|l|l|}
\hline Variable & $\begin{array}{c}\text { Sig (2 } \\
\text { tailed) }\end{array}$ & \multicolumn{1}{|c|}{ Simpulan } \\
\hline DER & 0,399 & $\begin{array}{l}\text { Bebas } \\
\text { heteroskedastisitas }\end{array}$ \\
\hline Ukuran & 0.090 & $\begin{array}{l}\text { Bebas } \\
\text { heteroskedastisitas }\end{array}$ \\
\hline Der *ROA & 0.120 & $\begin{array}{l}\text { Bebas } \\
\text { heteroskedastisitas }\end{array}$ \\
\hline Size*ROA & 0,110 & $\begin{array}{l}\text { Bebas } \\
\text { heteroskedastisitas }\end{array}$ \\
\hline
\end{tabular}

Uji menunjukkan bahwa nilai abs Res sig lebih besar 0,05 ditunjukkan data terjadi heteroskedastisitas.

\section{Hasil uji MRA}

Tabel 5 Pengujian MRA

\begin{tabular}{|l|c|c|c|l|}
\hline Variable & Coefficient & Nilai T & $\begin{array}{l}\text { Nilai } \\
\text { sig }\end{array}$ & Kesimpulan \\
\hline Der & 0.309 & 3,123 & 0,003 & berpengaruh \\
\hline Size & 0.053 & 3151 & 0,003 & berpengaruh \\
\hline Der "ROA & 0.544 & 3,944 & 0.000 & $\begin{array}{l}\text { Terjadi } \\
\text { moderasi }\end{array}$ \\
\hline Size"ROA & 0.112 & 0.804 & 0.422 & $\begin{array}{l}\text { Tidak terjadi } \\
\text { moderasi }\end{array}$ \\
\hline
\end{tabular}

\section{Pengaruh Struktur Modal Terhadap Nilai Per- usahaan}

Nilai perusahaan dipengaruhi struktur modal. Pengaruh positif ini memiliki dampak pada peningkatan nilai perusahaan. Pihak manajemen berhasil dalam membuat komposisi struktur modal yang terdapat pada operasi perusahaan.

Penelitian didukung (Bestariningrum, 2015; Hirdinis, 2019; Manoppo \& Arie, 2016; Rahman, 2012) yang dinyatakan struktur modal memengaruhi dan signifikansi pada nilai perusahaan. Peningkatan utang dapat meningkatkan nilai emiten.

Struktur modal yang bagus ialah struktur modal yang bisa meminimalkan beban modal yang meningkatkan nilai perusahaan. Penggunaan utang bisa memengaruhi harga saham. Penggunaan utang harus sesuai kebutuhan emiten serta bisa peningkatan nilai perusahaan.

Kebijakan manajemen pada penambahan utang pada jumlah tertentu untuk peningkatan nilai perusahaan. Hal ini terbukti bahwa penggunaan utang mempunyai pengaruh pada nilai perusahaan.

Tujuan perusahaan mempunyai utang adalah membantu dalam pengendalian penggunaan dana 
kas dengan bebas serta berlebihan pada pihak manajemen. .Adanya utang bisa membantu pengendalian penggunaan dana kas secara bebas serta berlebihan. Kebijakan digunakannya utang dalam struktur modal memberi kesempatan perusahaan untuk berkembang. Perkembangan ini akan meningkatkan investasi.

\section{Pengaruh Ukuran Perusahaan Terhadap Nilai Perusahaan}

Ukuran perusahaan menjadi indikator yang mempunyai pengaruh pada nilai perusahaan. Pengaruh negatif serta signifikan bersama nilai perusahaan jika ukuran perusahaan naik maka nilai perusahaan turun. Ukuran Perusahaan masih berupa aset dan inventaris. Perusahaan belum mampu membayar dividen kepada pemegang. Ukuran perusahaan memberikan dampak bagi nilai perusahaan (Halim \& Christiawan, 2017). Untuk memperoleh dana perusahaan menggunakan modal pribadi serta modal asing. Komposisi modal pribadi dan modal asing ditentukan kebijakan manajemen. Size perusahaan yang besar menunjukkan bahwa perusahaan mengalami perkembangan.

Hasil didukung (Hirdinis, 2019; Prasetya, 2016; Rahman, 2012) yang dinyatakan ukuran perusahaan mempunyai pengaruh negatif serta signifikansi pada nilai perusahaan. Penelitian tersebut berbanding dengan Bestariningrum (2015) yang menjelaskan ukuran perusahaan memengaruhi positif pada nilai perusahaan.

\section{Struktur Modal berpengaruh Terhadap Nilai Perusahaan Dimoderasi Kinerja Perusahaan}

Struktur modal memberikan pengaruh pada nilai perusahaan di moderasi kinerja emiten. Tolak ukur Kinerja keuangan melalui ROA dapat memperkuat hubungan struktur modal dengan nilai perusahaan. Penghasilan Laba oleh ROA dapat membuat investor menanamkan modalnya di emiten sehingga meningkatkan nilai perusahaan.

Struktur modal menjelaskan bandingan total non-current liabilities terhadap modal sendiri. Emiten harus mampu secara maksimal untuk membuat kebijakan yang efektif dan efisien dalam hal struktur modal. Struktur modal yang baik dapat memberikan hasil profit serta nilai perusahaan meningkat. Akan tetapi, jika pihak manajemen dalam perusahaan belum mampu membuat struktur modal yang baik dapat lebih berisiko bagi emiten. Struktur modal yang signifikan memiliki peningkatan kinerja perusahaan, jadi nilai saham emiten dapat ikut meningkat sejalan tercapainya kinerja perusahaan yang baik. Menurut pecking order theory untuk penggunaan komposisi struktur modal perusahaan dapat dipilih menggunakan dana kas dalam dulu, apabila dana luar diperlukan emiten dapat diterbitkan surat berharga paling aman terlebih dulu.

Perusahaan sektor konsumsi periode 20162018 sudah mengoptimalkan kinerja perusahaan. Laba yang dihasilkan dari penggunaan aset mampu mengurangi struktur modal dari luar serta peningkatan nilai perusahaan mampunya perusahaan untuk memiliki hasil profit akan meningkatkan nilai saham yang ada di pasar sehingga nilai perusahaan dapat ditingkatkan.

\section{Ukuran Perusahaan Terhadap Nilai Perusahaan Dimoderasi Kinerja Perusahaan}

Terdapat peneliti yang memberikan hasil size perusahaan memberikan pengaruh nilai perusahaan tidak dimoderasi kinerja emiten. Kinerja perusahaan belum mempunyai pengaruh terhadap keterkaitan ukuran perusahaan pada nilai 
perusahaan. Kinerja perusahaan dengan pengukuran melalui ROA belum mempunyai pengaruh pada ukuran perusahaan dan nilai perusahaan. Laba dihasilkan dari penggunaan aset masih berupa piutang dan inventaris sehingga belum mampu membawa investor dalam penanaman modal pada suatu emiten.

Perusahaan sektor konsumsi periode 20162018 belum mengoptimalkan kinerja perusahaan untuk membeli aset untuk meningkatkan nilai perusahaan. Laba yang dihasilkan dari penggunaan aset belum optimal sehingga tidak memengaruhi tingkat aset serta tingkat value perusahaan.

\section{KESIMPULAN}

1. Struktur modal memengaruhi nilai perusahaan. Komposisi struktur modal dapat menaikkan nilai perusahaan. Manajemen harus bias dalam pembuatan komposisi struktur modal yang tepat.

2. Ukuran perusahaan memiliki pengaruh pada nilai perusahaan. Jumlah aset emiten mencerminkan nilai perusahaan.

3. Struktur modal memengaruhi nilai perusahaan dimoderasi kinerja keuangan. Kinerja keuangan mampu menurunkan utang jangka panjang sehingga meningkatkan nilai emiten.

4. Ukuran perusahaan memiliki pengaruh pada nilai perusahaan tidak dimoderasi kinerja perusahaan. Laba yang dihasilkan tidak digunakan untuk membeli aset perusahaan sehingga tidak ada peningkatan nilai perusahaan.

\section{DAFTAR PUSTAKA}

Arviansyah, Y. 2013. Pengaruh Struktur Modal, Kinerja Keuangan Perusahaan, Pertumbuhan Perusahaan, dan Ukuran Perusahaan terhadap Nilai Perusahaan yang Terdaftar di Jakarta Islamic Index (JII) (Studi Empiris pada Perusahaan yang Terdaftar di JII Periode 2008-2011).

Bestariningrum, N. 2015. Analyzing The Effect of Capital Structure And Firm Size on Firm Value (Case Study: Company that Listed in Lq-45 Index Period 2010-2014). Jurnal Berkala Ilmiah Efisiensi, 15(4).

Fachrudin, K. A. 2011. Analisis Pengaruh Struktur Modal, Ukuran Perusahaan, dan Agency Cost Terhadap Kinerja Perusahaan. Jurnal Akuntansi dan Keuangan, 13(1), 3746.

Halim, H. A. \& Christiawan, Y. J. 2017. Pengaruh Penerapan Corporate Governance terhadap Nilai Perusahaan dengan Ukuran Perusahaan dan Umur Perusahaan sebagai Variabel Kontrol. Business Accounting Review, 5(2), 181-192.

Hirdinis, M. 2019. Capital Structure and Firm Size on Firm Value Moderated By Profitability.

Liem, J. H., Murhadi, W. R., \& Sutejo, B. S. 2013. Faktor-Faktor yang Memengaruhi Struktur Modal pada Industri Consumer Goods yang Terdaftar di BEI Periode 2007-2011. Calyptra, 2(1), 1-11.

Manoppo, H. \& Arie, F. V. 2016. The Influence of Capital Structure, Company Size and Profitability towards Automotive Company Value of IDX Period 2011-2014. Journal EMBA, 4(2), 485-497.

Murhadi, W. R. 2013. Analisis Laporan Kenangan: Proyeksi dan Valuasi Saham. Salemba Empat.

Novari, P. M. \& Lestari, P. V. 2016. Pengaruh Ukuran Perusahaan, Leverage, dan Profitabilitas Terhadap Nilai Perusahaan pada Sektor Properti dan Real Estate. E-Jurnal Manajemen Universitas Udayana, 5(9). 
Prasetya, P. J. 2016. Pengaruh Ukuran Perusahaan terhadap Manajemen Laba dengan Pengungkapan Corporate Social Responsibility Sebagai Variabel Intervening. EJurnal Akuntansi Universitas Udayana, 14 (1), 511-538.

PT Bursa Efek Indonesia. (n.d.). PT Bursa Efek Indonesia. Retrieved July 26, 2020, from https://www.idx.co.id/data-pasar/datasaham/daftar-saham/.
Rahman, S. 2012. The Role of Intellectual Capital in Determining Differences between Stock Market and Financial Performance. International Research Journal of Finance and Economics, 89(1), 46-77.

Wirajaya, A. \& Dewi, A. S. M. 2013. Pengaruh Struktur Modal, Profitabilitas dan Ukuran Perusahaan pada Nilai Perusahaan. E-Jurnal Akuntansi Universitas Udayana, 4(2), 358372. 